\title{
WORKSHOP E-LEARNING GOOGLE CLASSROOM DAN VIDEO PEMBELAJARAN PADA SMP N 35 PEKANBARU
}

\author{
Yoyon Efendi ${ }^{*}$, Lusiana ${ }^{2}$, Rometdo Muzawi $^{3}$, Rini Yanti ${ }^{4}$, Syahrul Imardi ${ }^{5}$ \\ 1,2,3,4,5STMIK Amik Riau, Pekanbaru, Indonesia \\ *Penulis Koresponsensi, email: yoyonefendi@stmik-amik-riau.ac.id
}

Received:15/01/2021

Revised:16/02/2021

Accepted:18/02/2021

\begin{abstract}
Learning problems are often the reason teachers do not provide material in class optimally. Like condition COVID 19 at this time, apart from that, for various reasons, such as the teacher having a meeting, the city office is an obstacle for teachers to deliver material at school, even students roaming around and fighting in class. An effective and efficient learning media is needed for teachers to continue delivering material even under any circumstances. Learning using Google Classroom, one way to face the challenges of the technology world in education through learning media. Besides that, the making of instructional videos will increase the creativity of teachers to make interesting and interactive teaching materials. This workshop was attended by 21 teachers from SMP N 35 Pekanbaru. After going through the pre-test and post-test, there was an increase in the knowledge and skills of teachers in managing classes on Google Classroom and learning videos. This workshop can be a provision for teaching and learning activities at school and outside of school.
\end{abstract}

Keywords: Workshop, E-Learning, Classroom, SMP N 35 Pekanbaru

Abstrak. Masalah pembelajaran sering menjadi alasan guru-guru tidak maksimal memberikan materi di kelas. Seperti Susana COVID 19 pada saat ini selain itu juga dengan berbagai alasan seperti guru lagi rapat, dinas luar kota menjadi halangan guru menyampaikan materi di sekolah bahkan siswa berkeliaran dan rebut dikelas. Diperlukan media pembelajaran yang efektif dan efisien bagi guru untuk tetap menyampaikan materi walau dalam kondisi apapun. Pembelajaran menggunakan Google Classroom, salah satu cara untuk menghadapi tantangan dunia teknologi pada bidang pendidikan melalui media pembelajaran. Disamping itu adanya pembuatan video pembelajaran akan meningkatkan kreatifitas guru untuk membuat materi ajar yang menarik dan interaktif. Workshop ini diikuti oleh 21 orang guru-guru dari SMP N 35 Pekanbaru. Setelah melalui Pre-test dan Post-test terjadi peningkatan pengetahuan dan keahlian guru dalam mengelola kelas pada Google Classroom dan video pembelajaran. Workshop ini dapat menjadi bekal dalam kegiatan belajar mengajar di sekolah maupun luar sekolah.

Kata Kunci: Workshop, E-Learning, Classroom, SMP N 35 Pekanbaru

How to Cite: Efendi, Y., Lusiana, L., Muzawi, R., Yanti, R., \& Imardi, S. (2021). WORKSHOP E-LEARNING GOOGLE CLASSROOM DAN VIDEO PEMBELAJARAN PADA SMP N 35 PEKANBARU. Mitra Mahajana: Jurnal Pengabdian Masyarakat, 2(1), 82-89.

https://doi.org/10.37478/mahajana.v2i1.789

\section{PENDAHULUAN}

Sekolah Menengah Pertama (SMP) Negeri 35 Pekanbaru merupakan SMP dengan akreditasi A di kota Pekanbaru. Dengan jumlah guru 31 orang dan 600 siswa serta memiliki 16 ruangan kelas. Sekolah yang terletak jalan T.Bey/ Reformasi II Simpang Tiga Pekanbaru. Sekolah ini berusaha meningkatkan kualitas tenaga pengajar dengan menfasilitasi kegiatankegiatan dalam kondisi daring seperti Google Classroom, salah satunya dalam media pembelajaran. Ada beberapa media e-learning seperti googleclassroom , moodle dan edmodo. Googleclassroom, khusus e-learning merupakan salah satu dari Google Aps For Education (GAFE)(Efendi \& Utami, 2019)

Media pembelajaran merupakan pilar yang sangat penting pada sebuah sekolah. Dengan meningkatnya pengetahuan guru akan berdampak positif dalam kegiatan belajar mengajar walaupun dalam kondisi apapun. Seperti guru rapat, dinas keluarga, dan sebagainya. Tidak ada alasan tidak masuk kelas dan tidak memberikan alasan tidak membagikan materi walaupun dari rumah sekalipun. Dengan demikian penggunaan media dalam pengajaran di kelas merupakan sebuah kebutuhan yang tidak dapat diabaikan. Hal ini dapat dipahami mengingat proses belajar yang dialami siswa tertumpu pada berbagai kegiatan menambah ilmu 
dan wawasan untuk bekal hidup di masa sekarang dan masa akan datang(Efendi \& Utami, 2019)(Mahnun, 2012).

Secara umum ICT dalam pembelajaran dapat diartikan sebagai pengunaan media internet dalam proses pembelajaran. Dalam sudut pandang yang lebih sederhana, pengunaan komputer, projektor, tv, radio dan alat elektronik lainnya dalam proses pembelajaran juga dianggap sebagai bentuk dari pengunaan ICT (El Fauziah et al., 2019). Saat ini sudah banyak sekolah-sekolah yang menggunakan teknologi informasi dan komunikasi dalam pembelajaran(Salamah, 2020).

Berdasarkan kejadian yang terjadi di Indonesia saat ini akibat pandemi COVID-19, kegiatan belajar mengajar menjadi terhambat karena kegiatan belajar di sekolah dan universitas ditiadakan(Hisyam Surya, Euis Ismayati, Achmad Imam, 2020). Masalah yang dihadapi mitra ada 3 yaitu rendahnya pengetahuan guru dalam Media Pembelajaran, rendahnya guru dalam teknologi Pembelajaran dan video pembelajaran serta kurangnya guru dalam penggunaan aplikasi pembelajaran google classroom. Maka diperlukan workshop untuk guruguru untuk meningkatkan pengetahuan tentang Goole Classroom, mengerjakan kelas dengan Goole Classroom dengan studi kasus sekolah. Di samping itu juga guru dapat memahami dan mengerti video Pembelajaran serta diterapkan di sekolah dengan berbagai mata pelajaran.

Workshop ini diharapkan dapat memacu minat guru dalam mempelajari media pembelajaran Goole Classroom dengan baik dan benar. Selain itu juga guru mampu mengaplikasikan video pembelajaran sesuai dengan materi ajar masing-masing guru. Desain aplikasi Google classroom memang ramah lingkungan. Hal tersebut dikarenakan peserta didik tidak menggunakan kertas dalam mengumpulkan tugasnya(Rahmanto \& Bunyamin, 2020).

Salah satu metode pembelajaran online yang saat ini sedang berkembang dan mulai digunakan adalah google classroom. Google Classroom adalah aplikasi yang dikhususkan untuk media pembelajaran online atau istilahnya adalah kelas online sehingga dapat memudahkan guru dalam membuat, membagikan serta mengelompokkan setiap tugas tanpa menggunakan kertas lagi(Soni et al., 2018) .

Google Classroom merupakan sebuah aplikasi yang memungkinkan terciptanya ruang kelas didunia maya. Selain itu, google classroom bisa menjadi sarana distribusi tugas, submit tugas bahkan menilai tugas-tugas yang dikumpulkan(Nirfayanti \& Nurbaeti, 2019). Melalui aplikasi Google Classroom diasumsikan bahwa tujuan pembelajaran akan lebih mudah direalisasikan dan sarat kebermaknaan. Oleh karena itu, penggunaan Google Classroom ini sesungguhnya mem- permudah guru dalam mengelola pembelajaran dan menyampaikan informasi secara tepat dan akurat kepada peserta didik(Sabran \& Sabara, 2019).

Pada saat sekarang ini guru dituntut untuk menguasai teknologi guna memberikan kemudahan kepada siswa dalam belajar. Guru bisa menggunakan jenis media audio visual yang mampu mem-berikan kejelasan terhadap suatu materi yang dipelajari. Jenis media audio visual bisa berupa video pembelajaran. pemanfaatan video dapat meningkatkan kemampuan bahasa siswa. Dari penguasaan bahasa yang meningkat tentu akan mempermudah siswa dalam memahami materi yang disampaikan (Suryansah \& Suwarjo, 2016).

\section{METODE PELAKSANAAN}

Pendekatan yang digunakan pada pengabdian masyarakat di SMP N 35 Pekanbaru adalah Materi di lengkapi dengan modul, project mobile, video tutorial dan studi kasus. Pemecahan Masalah melalui presentasi konsep pembelajaran google classroom dan video pembelajaran untuk mendukung pemahaman peserta pelatihan di dampingi oleh Tutor yang berpengalaman.

Pendekatan cara pemecahan masalah yang dilakukan yaitu: Memberikan motivasi kepada peserta pelatihan, Menggali pengetahuan peserta akan media pembelajaran (pre-test), Konsistensi materi pelatihan, Mengajak peserta untuk aktif dalam pelatihan, Pratikum sebagai 
penerapan google classroom, Pratikum sebagai penerapan Video Pembelajaran dan Evaluasi pelatihan sebagai tolak ukur hasil luaran(post-test).

Workshop tersebut diberikan langsung oleh tim dosen STMIK Amik Riau sebanyak 5 orang dan 2 orang mahasiswa dari prodi Teknik Informatika. Formasi dosen dan mahasiswa yang mengikuti PKM di SMP Negeri 35 Pekanbaru dapat dilihat pada Tabel 1 sebagai berikut:

Tabel 1. Formasi Dosen dan Mahasiswa PKM di SMP Negeri 35 Pekanbaru

\begin{tabular}{llc}
\hline \multicolumn{1}{c}{ Nama } & Status & Prodi \\
\hline Yoyon Efendi, M.Kom & Dosen & Teknologi Informasi \\
Lusiana, M.Kom & Dosen & Teknik Informatika \\
Rometdo Muzawi, M.Kom & Dosen & Manajemen Informatika \\
Syahrul Imardi, MT & Dosen & Teknik Informatika \\
Rini Yanti, M.Mat & Dosen & Teknik Informatika \\
Zel Afriadi & Mahasiswa & Teknik Informatika \\
Bambang Permadi & Mahasiswa & Teknik Informatika \\
\hline
\end{tabular}

Media pelatihan yang digunakan adalah sebagai berikut: pertama, media proyektor dan laptop untuk menampilkan secara visual mengenai materi pelatihan yang akan dissampaikan. Kedua, laser pointer, yang digunakan untuk memberikan kesan lebih interaktif dalam menyajikan bahan pelatihan bagi guru, sehingga lebih dapat memunculkan semangat bagi guru dalam kegiatan pelatihan. Ketiga, modul pratikum dilengkapi contoh -contoh studi kasus.

\section{HASIL DAN PEMBAHASAN}

Pelaksanaan Kegiatan Pengabdian Kepada Masyarakat ini dilaksanakan 2 hari mulai dari 12-13 November 2020. Kegiatan ini memiliki rundown acara yang terbagi atas 4 sesi sesuai dengan tabel 2 sebagai berikut:

Tabel 2. Rundown acara Pengabdian Kepada Masyarakat di SMP N 35 Pekanbaru

\begin{tabular}{ccll}
\hline Sesi & Jam & \multicolumn{1}{c}{ Kegiatan } & \multicolumn{1}{c}{ Instruktur } \\
\hline Hari Pertama & & & \\
Sesi I & $08.00-08.30$ & Pembukaan oleh Kepala Sekolah & Indrayani, S.Pd \\
& $08.30-09.00$ & Sambutan dari STMIK Amik Riau & Yoyon Efendi, M.Kom \\
& $09.00-09.15$ & Foto Bersama & Tim \\
Sesi II & $09.15-09.20$ & Pre-Test & Tim \\
& $09.20-10.15$ & Konsep E-Learning & Rini Yanti, M.Mat \\
& $10.15-12.00$ & Pembelajaran Google Classroom & Lusiana, M.Kom \\
Hari Kedua & & & \\
Sesi III & $08.00-09.30$ & Video Pembelajaran OBS & Rometdo Muzawi, M.Kom \\
& $09.30-11.00$ & Video Pembelajaran Camtasia & Syahrul Imardi, MT \\
Sesi IV & $11.00-11.05$ & Post-Test & Tim \\
& $11.05-11.20$ & Penutupan dari STMIK Amik Riau & Lusiana, M.Kom \\
& $11.20-11.35$ & Penutupan oleh Kepala Sekolah & Indrayani, S.Pd \\
& $11.35-11.50$ & Foto Bersama & Tim \\
\hline
\end{tabular}

Pada sesi I dimulai kata sambutan dari Kepala Sekolah SMP Negeri 35 Pekanbaru, Indrayani, S.Pd. dalam sambutan nya : "menyambut baik kegiatan ini yang sangat berguna bagi guru-guru di tengah pandemi yang kegiatan pembelajaran bersifat daring". 


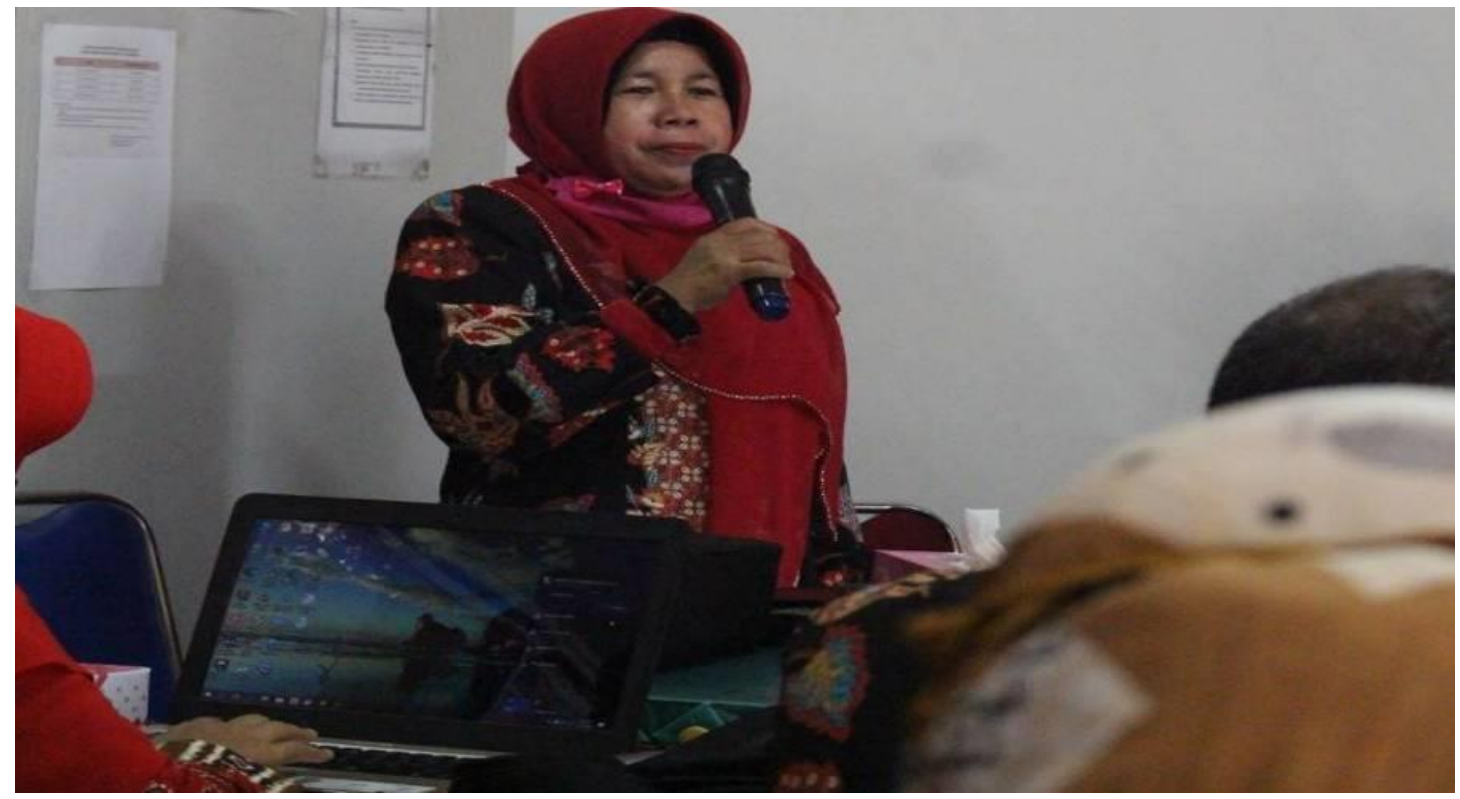

Gambar 1. Sambutan Kepala Sekolah sekalian pembukaan acara Workshop

Selanjutnya kata sambutan dari ketua tim Pengabdian Kepada Masyarakat (PKM) mewakili STMIK Amik Riau: Yoyon Efendi, M.Kom, dalam sambutannya: " kegiatan ini merupakan salah satu kegiatan Tri Dharma seorang dosen yaitu pengabdian masyarakat". Pada semester ini dilaksanakan di SMP Negeri 35 Pekanbaru.

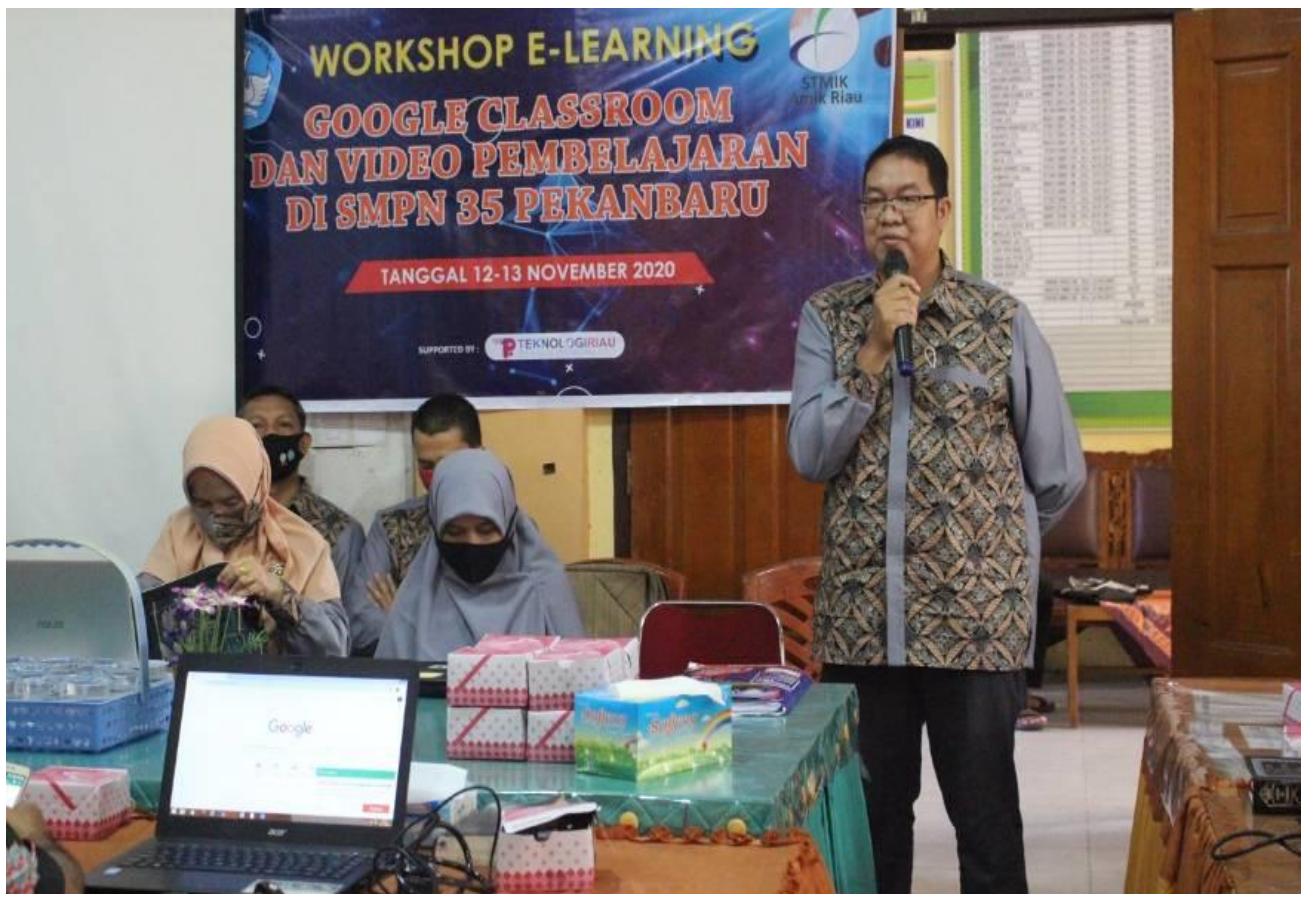

Gambar 2. Ketua PKM memberikan kata sambutan pembukaan workshop

Pada sesi kedua, dimulai dengan materi Konsep E-Learning oleh Rini Yanti, M.Mat, dalam materinya disampaikan bahwa E-Learning dikenal dengan berbagai macam seperti Google Classroom, Edmodo, dan lainnya. Lalu dilanjutkan oleh Lusiana, M.Kom dengan materi Google Classroom mulai dari buat kelas, upload materi, penilaian dan rekapitulasi nilai. 


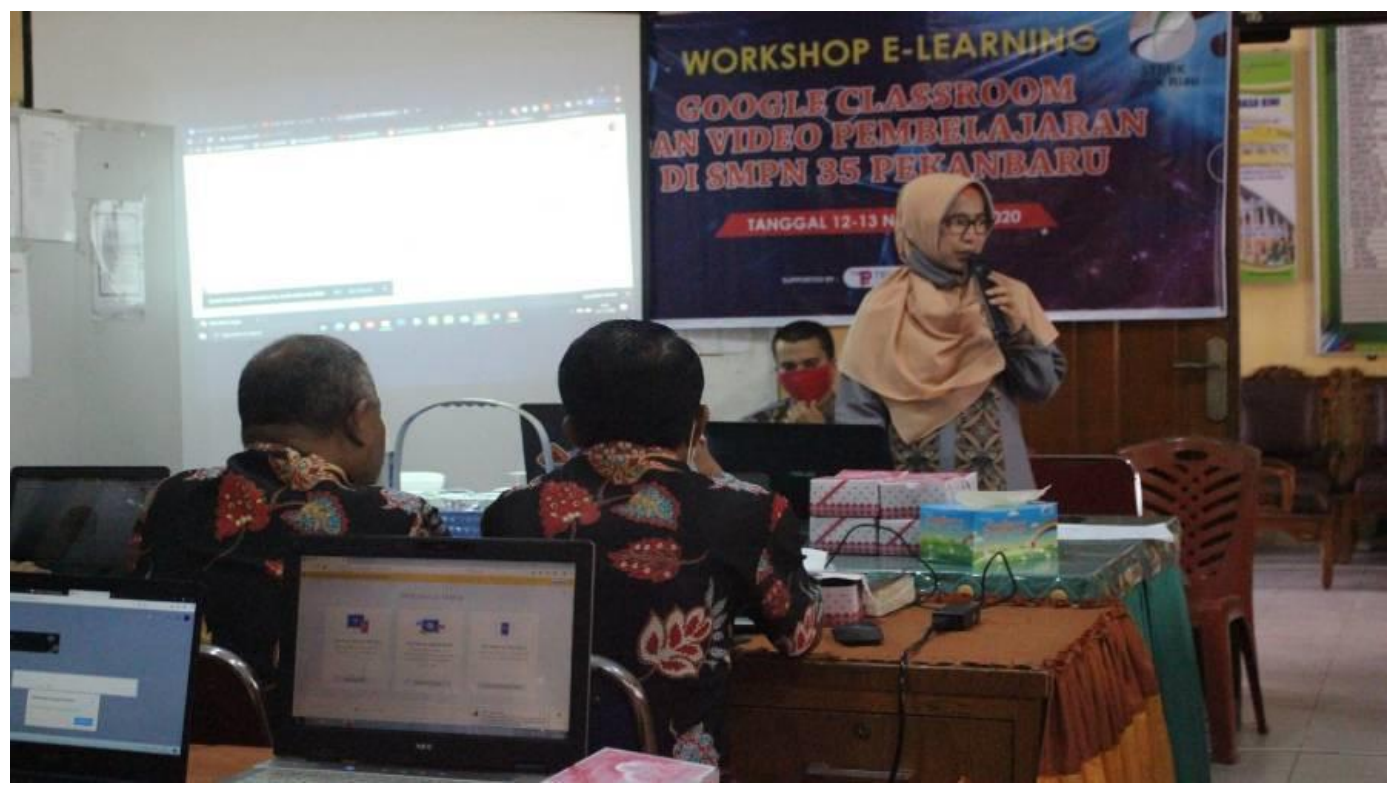

Gambar 3. Lusiana, M.Kom menyampaikan materi Google Classroom

Kegiatan Workshop ini disambut antusias oleh guru-guru pada SMP Negeri 35 Pekanbaru. Walaupun di masa Covid 19 pelaksanaan workshop ini diikuti dengan seksama walaupun ini pertama kali guru-guru menggunakan google classroom.

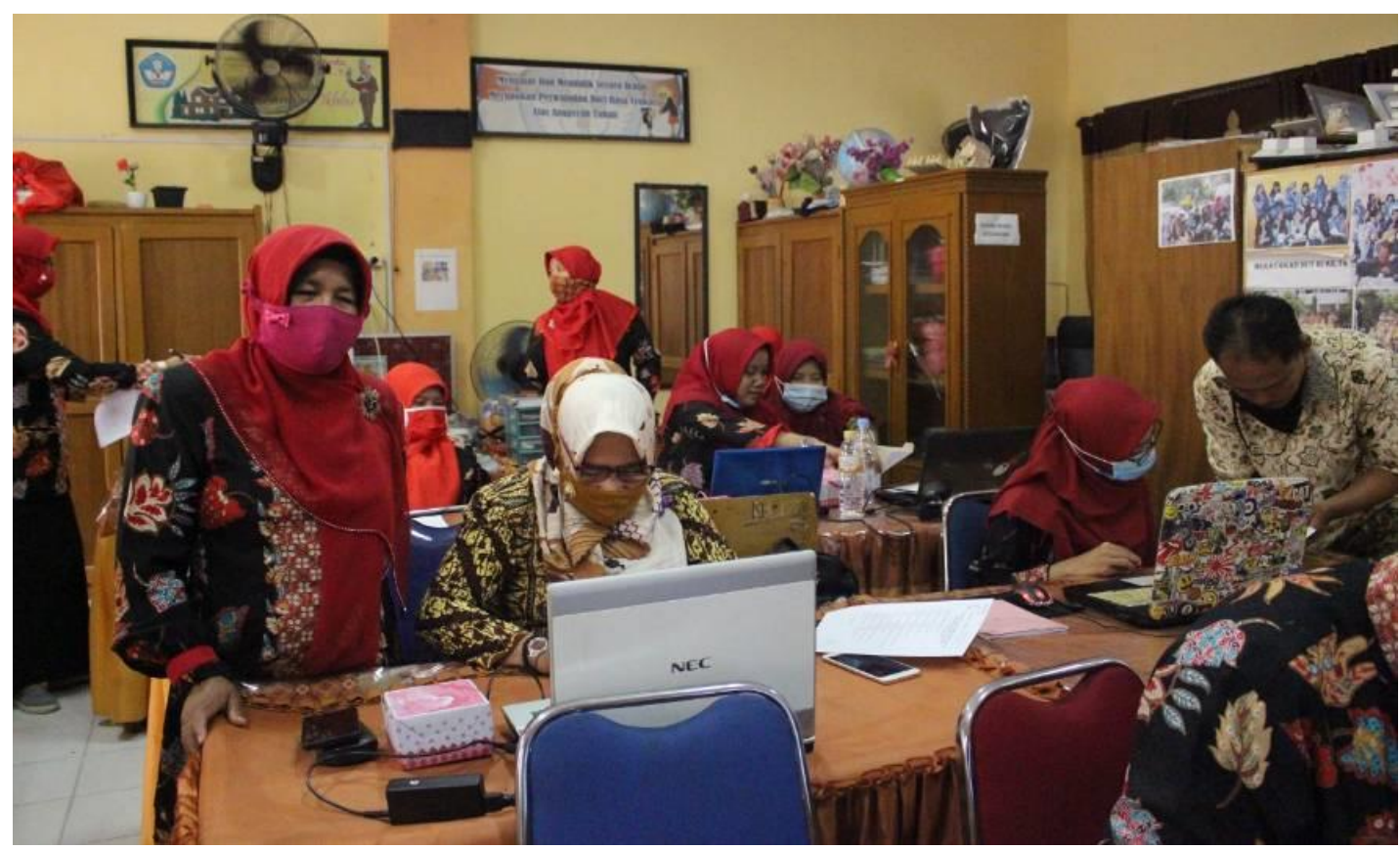

Gambar 4. Suasana workshop yang diikutioleh guru-guru

Kegiatan pada hari kedua ditutup dengan foto bersama dengan guru-guru sebagai peserta dan narasumber dari dosen-dosen STMIK Amik Riau. Sebagai kata penutup dari kepala sekolah :" semoga kegiatan ini bukan terakhir dan berharap berkelajutan karena workshop ini sangat dibutuhkan oleh guru-guru di SMP Negeri 35 Pekanbaru". 


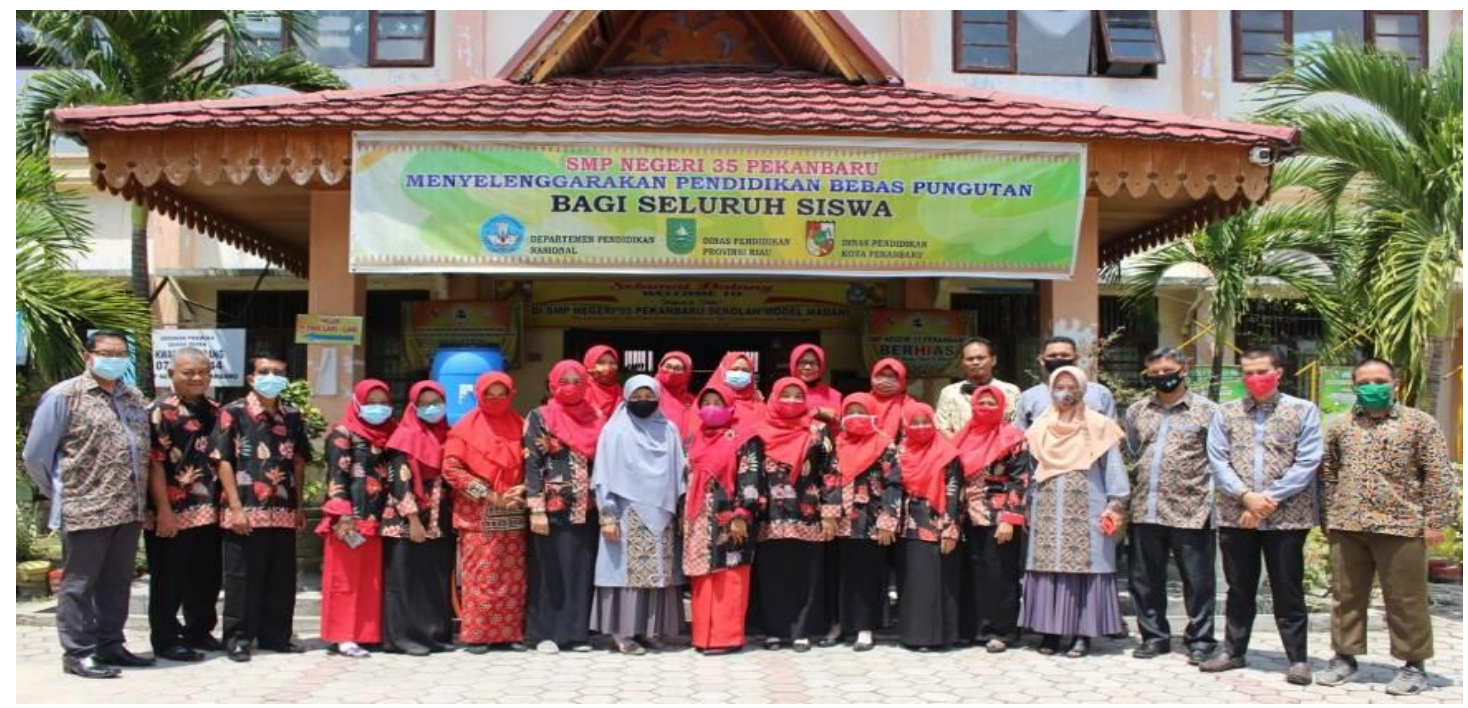

Gambar 5. Foto bersama peserta dan narasumber workshop

Hasil Evaluasi terhadap kegiatan Workshop pembelajaran daring menggunakan Google Classroom di SMP Negeri 35 Pekanbaru dengan meningkatnya pengetahuan guru dalam pembelajaran Google Classroom dan Video Pembelajaran. Workshop ini memberikan sesi pratikum dan evaluasi hasil pembelajaran menggunakan Google classroom dan Video Pembelajaran oleh guru-guru SMP Negeri 35 Pekanbaru. Hasilnya terjadi peningkatan pengetahuan dan keahlian guru-guru menggunakan Google Classroom melalui Pre-test dan Post-test seperti terlihat pada tabel 3 sebagai berikut:

Tabel 3. Pre-test dan post-test Workshop

\begin{tabular}{cccccc}
\hline & Pre-Test & \multicolumn{4}{c}{ Post-Test } \\
\hline Jawaban & Jumlah & $\%$ & Jawaban & Jumlah & $\%$ \\
\hline Benar 1 & 10 & $48 \%$ & Benar 6 & 1 & $5 \%$ \\
Benar 2 & 5 & $24 \%$ & Benar 7 & 5 & $24 \%$ \\
Benar 3 & 5 & $24 \%$ & Benar 8 & 8 & $38 \%$ \\
Benar 4 & 1 & $5 \%$ & Benar 9 & 7 & $33 \%$ \\
\hline
\end{tabular}

Dari 21 orang peserta yang terdiri dari guru- guru SMP N 35 Pekanbaru untuk menghadiri pengabdian kepada masyarakat " Workshop E-Learning Google Classroom dan Video Pembelajaran di SMP N 35 Pekanbaru”. Setelah pelaksanaan pelatihan, nampak peningkatan pengetahuan guru-guru secara signifikan. Terlihat semua peserta mampu menyelesaikan tugas pratikum yang diberikan. Oleh sebab itu diharapkan peserta pelatihan dapat memanfaatkan pengetahuan ini untuk mampu mengembangkan diri dalam pembelajaran google classroom dan video pembelajaran.

Hasilnya dapat dilihat dari grafik perbandingan pre-test dan post-test yang dilakukan oleh tim PKM. 

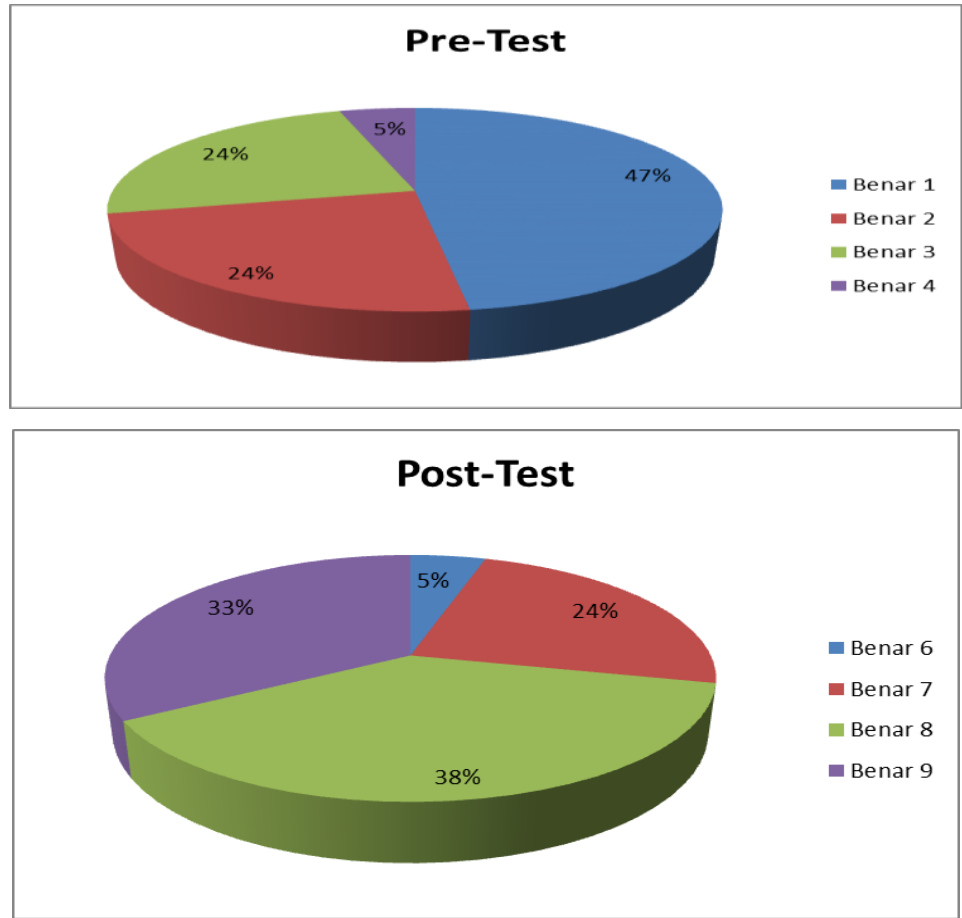

Gambar 6. Grafik Pre-test dan Post-Test

Pelaksanaan PKM ini, dilaporkan secara tertulis dalam laporan kegiatan yang dilengkapi dengan poster. Poster ini sebagai gambaran secara umum Workshop Google Classroom dan Video Pembelajaran pada SMP Negeri 35 Pekanbaru.

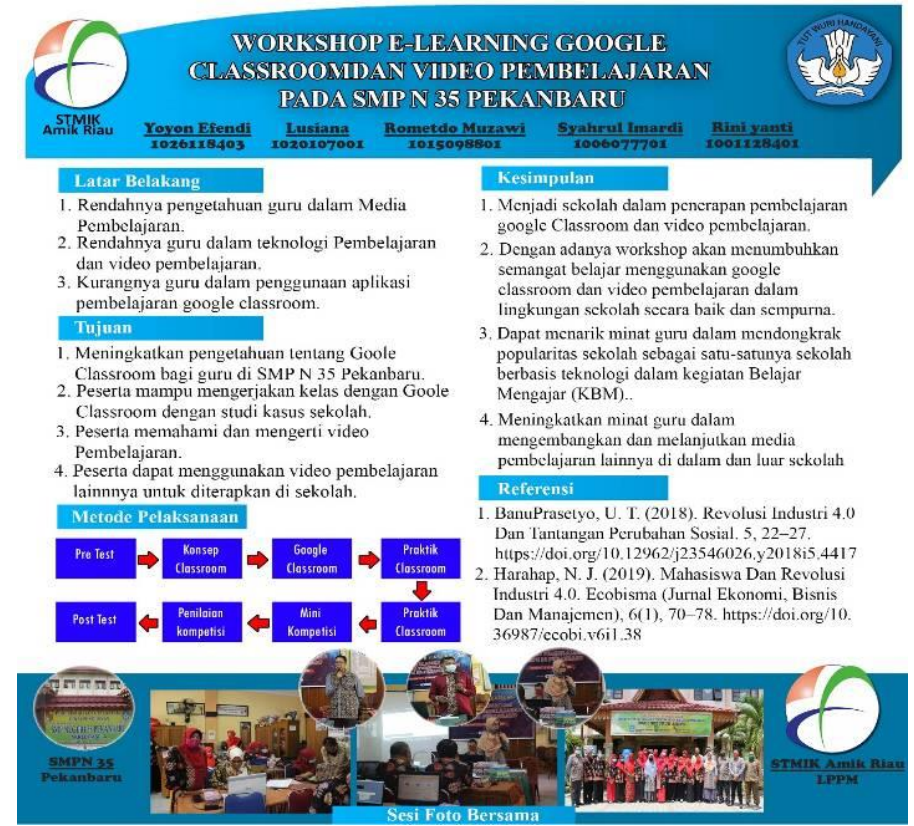

Gambar 6 Poster kegiatan workshop dari PKM

\section{SIMPULAN DAN TINDAK LANJUT}

Simpulan yang didapat dari Workshop ini yaitu menjadi sekolah dalam penerapan pembelajaran google Classroom dan video pembelajaran.Dengan adanya workshop akan menumbuhkan semangat belajar menggunakan google classroom dan video pembelajaran 
dalam lingkungan sekolah secara baik dan sempurna. Dapat menarik minat guru dalam mendongkrak popularitas sekolah sebagai satu-satunya sekolah berbasis teknologi dalam kegiatan Belajar Mengajar (KBM). Meningkatkan minat guru dalam mengembangkan dan melanjutkan media pembelajaran lainnya di sekolah dan di luar sekolah.

Tindaklanjut yang diperlukan pelatihan media pembelajaran lanjutan untuk mengasah minat dan kemampuan guru dengan lebih dalam. Selain itu diperlukan perangkat penunjang pelatihan teknologi pembelajaran yang lebih baik dan koneksi internet yang lebih stabil.

\section{DAFTAR PUSTAKA}

Efendi, Y., \& Utami, N. (2019). Pengukuran Efektifitas Pembelajaran Menggunakan Media ELearning Google Classroom ( SMK Sulthan Muazzamsyah Pekanbaru ). Prosiding Seminar Nasional Computation Technology and Its Aplication, 1(1), 1-4. https://ejurnal.umri.ac.id/index.php/CTIA/article/view/1822

El Fauziah, U. N., Suryani, L., \& Syahrizal, T. (2019). Penerapan Google Classroom Dalam Pembelajaran Bahasa Inggris Kepada Guru-Guru Bahasa Inggris Smp Di Subang. Abdimas Siliwangi, 2(2), 183. https://doi.org/10.22460/as.v2i2p183-191.3281

Hisyam Surya, Euis Ismayati, Achmad Imam, T. R. (2020). MEDIA E-LEARNING BERBASIS GOOGLE CLASSROOM UNTUK MENINGKATKAN HASIL BELAJAR SISWA SMK Hisyam Surya Su ' uga Euis Ismayati , Achmad Imam Agung, Tri Rijanto. 09 (3).

Mahnun, N. (2012). Media Pembelajaran (Kajian terhadap Langkah-langkah Pemilihan Media dan Implementasinya dalam Pembelajaran). An-Nida', 37(1), 27-35.

Nirfayanti, N., \& Nurbaeti, N. (2019). Pengaruh Media Pembelajaran Google Classroom Dalam Pembelajaran Analisis Real Terhadap Motivasi Belajar Mahasiswa. Proximal, 2(1), 50-59. https://doi.org/https://doi.org/10.30605/2615-7667.211

Rahmanto, M. A., \& Bunyamin. (2020). Efektivitas Media Pembelajaran Daring Melalui Google Classroom. Jurnal Pendidikan Islam, 11(November), 119-135.

Sabran, \& Sabara, E. (2019). Keefektifan Google Classroom sebagai media pembelajaran. PROSIDING SEMINAR NASIONAL LEMBAGA PENELITIAN UNIVERSITAS NEGERI Makasar, 122-125.

https://webcache.googleusercontent.com/search?q=cache:SS_jKM_r2TAJ:https://ojs.unm. ac.id/semnaslemlit/article/download/8256/4767+\&cd=2\&hl=id\&ct=clnk\&gl=id

Salamah, W. (2020). Deskripsi Penggunaan Aplikasi Google Classroom dalam Proses Pembelajaran. Jurnal Penelitian Dan Pengembangan Pendidikan, 4(1), 533-538. https://ejournal.undiksha.ac.id/index.php/JJL/article/view/29099

Soni, Hafid, A., Hayami, R., Fatma, Y., Wenando, F. A., Amien, J. Al, Fuad, E., Unik, M., Mukhtar, H., \& Hasanuddin. (2018). Optimalisasi Pemanfaatan Google Classroom Sebagai Media Pembelajaran Di SMK Negeri 1 Bangkinang. Jurnal Pengabdian Untuk Mu NegeRI, 2(1), 1720. https://www.researchgate.net/publication/331703602\%0AOPTIMALISASI

Suryansah, T., \& Suwarjo, S. (2016). Pengembangan Video Pembelajaran Untuk Meningkatkan Motivasi Dan Hasil Belajar Kognitif Siswa Kelas Iv Sd. Jurnal Prima Edukasia, 4(2), 209. https://doi.org/10.21831/jpe.v4i2.8393 